\title{
Karyological sexing and sex ratio of Japanese quail embryos
}

\author{
Midori Yoshizawa, Ikumi Noguchi*, Takashi Muramatsu \\ and Akira Oкамото \\ Department of Animal Breeding and Reproduction, \\ Faculty of Agriculture, Utsunomiya University, Utsunomiya 321 \\ *Present address: Toxicology Group, Research Laboratory, \\ Mitsubishi Yuka Pharmaceutical Co., Ltd., Ibaraki 300-03
}

\begin{abstract}
Summary. The sex ratio of quail embryos at 16 hours of incubation was measured on the basis of karyological sexing. Chromosome preparations were made from Colcemid-primed blastodiscs by the air- or fire-drying method followed by conventional Giemsa staining. A method for preparing chromosome slides from the telolecital eggs of birds was described in some detail. Sexing was made by ascertaining the sex chromosome constitution, ZZ (male) or $\mathrm{ZW}$ (female), for a minimum of five metaphase plates per embryo. A total of 305 embryos were prepared for cytological sexing. Of these 274 embryos, about $90 \%$ could be sexed successfully. The embryos sexed as male were 138 and those sexed as female were 136 , a sex ratio of 50.4 ( $\%$ males) being very close to the fifty-fifty ratio.
\end{abstract}

(Japan. J. Anim. Reprod., 31 236-242, 1985)

\section{Introduction}

Karyological sexing of avian discoidal embryos has so far been made in the domestic fowl and the chicken-quail hybrid. Studies on the domestic fowl ${ }^{1,2)}$ showed that embryonic sex ratio does not deviate significantly from equality at the initial stage of incubation. This virtual equality of early embryonic ratio was also confirmed even in the closed flocks of fowl which had showed a slight, but habitual deficiency of male chicks in the secondary sex ratio during the previous seven years of inbreeding ${ }^{2)}$. From these results it was supposed that the primary sex ratio is also nearly equal in the fowl. A few studies in the chicken-quail hybrid ${ }^{3,4)}$ showed that females are present during the early stage of incubation, but they suffer greater mortality than males in the course of incubation to end in absence at hatching.

The present study was undertaken to provide further information on the embryonic sex ratio in birds. Japanese quail was used since little information is available of this species.

\section{Materials and Methods}

Japanese quail (Coturnix coturnix japonica) for use were purchased from a commercial breeder. Parental quail, 9-12 months old, were kept in pairing four or five females with a male under conditions of continuous artificial light. Eggs to be incubated were placed in a horizontal position with the top of shell-surface marked. This posture has been maintained throughout the period of incubation so that the blastodisc is settled under the top marked. Preliminarily, eggs were incubated at $38^{\circ} \mathrm{C}$ for about 16 hours. After incubation, a hole was bored at the top mark, through which $0.05 \mathrm{ml}$ of a $10 \mu \mathrm{g} / \mathrm{ml}$ solution of Colcemid was injected into vitellus closest to the blastodisc. The hole was sealed with cellophane paper, and eggs were incubated at $38^{\circ} \mathrm{C}$ for additional 
four hours. The content of egg was then emptied into a petri dish. The blastodisc was dissected out and immediately placed in a watch glass containing Tyrode solution. Scraps of the vitelline membrane and yolk fragments, if they adhered to the disc, were shaked off into this solution. The denuded blastodisc was transferred to a centrifuge tube containing $5 \mathrm{ml}$ of $0.45 \%$ sodium citrate solution, in which cell suspension was made by repeating gentle passing of the contents of the tube with a Pasteur pipette. The suspension was then allowed to stand at $38^{\circ} \mathrm{C}$ for 15 to 20 minutes. To make mild fixation we added $5 \mathrm{ml}$ of acetic-methanol (1:3) to the suspension. The mixture was centrifuged at $800 \mathrm{rpm}$ for five minutes, and the supernatant fluid was replaced by $5 \mathrm{~m} l$ of fresh acetic-methanol. This procedure of fixation was repeated twice. The final precipitate was resuspended in about $0.5 \mathrm{ml}$ of fixative which had remained in the bottom of the tube after the last centrifugation. This concentrated cell suspension was dropped on a slide wet with $60 \%$ ethanol, two or three drops for each slide being suitable. Air- or fire-dried slides were made and stained in $3 \%$ Giemsa solution for 10 minutes. In each blastodisc, sexing was made for a minimum of five metaphase plates showing the complete diploid number (78) of chromosomes. The sex was diagnosed independently by two observers to check possible personal error.

The arm lengths of the chromosomes were measured on photographs with a vernier caliper and chromosome types as to the position of the centromere were classified according to the criteria proposed by LEVAN et al..$^{5)}$

\section{Results}

General pictures of metaphase plates obtained from quail embryos are shown in Figs. 1 and 2, where chromosome components are also shown in the form of karyotype. We made this sort of karyotype for the majority of metaphase plates photographed, and ascertained that the normal diploid number of chromosomes is 78 .

The $Z$ chromosome was found to rank among the three autosomes from No. 3 to No. 5 in the order of decreasing length. It showed a typical metacentric form having an arm ratio of about 1.1, and it was easily distinguishable from other large chromosomes; chromosome No. 1 was submetacentric with an arm ratio of about 2.5 , No. 2 was metacentric but distinctive by its arm ratio of 1.6, No. 3 was telocentric, and No. 4 was acrocentric with its centromere very close to its end.

On the other hand, the $\mathrm{W}$ chromosome was difficult to distinguish from the autosome pair of No. 5 because these three were nearly equal in length and seemingly telocentric in shape. Close examination of better prepared metaphase plates showed that one of the three chromosomes had a tiny projection beyond the centromere, projection which resembles a short arm of acrocentric form, whereas the other two were certainly telocentric (Fig. 3). It was also observed that this one had no homologous partner and coexisted with one $\mathrm{Z}$ chromosome. Thus we regarded this one as the $\mathrm{W}$ chromosome. Occasionally, the tiny projection was ill defined even in close examination and the $\mathrm{W}$ chromosome could not be identified with certainty. However the presence of the $\mathrm{W}$ chromosome could be known by detecting the excess one 



Fig. 1 

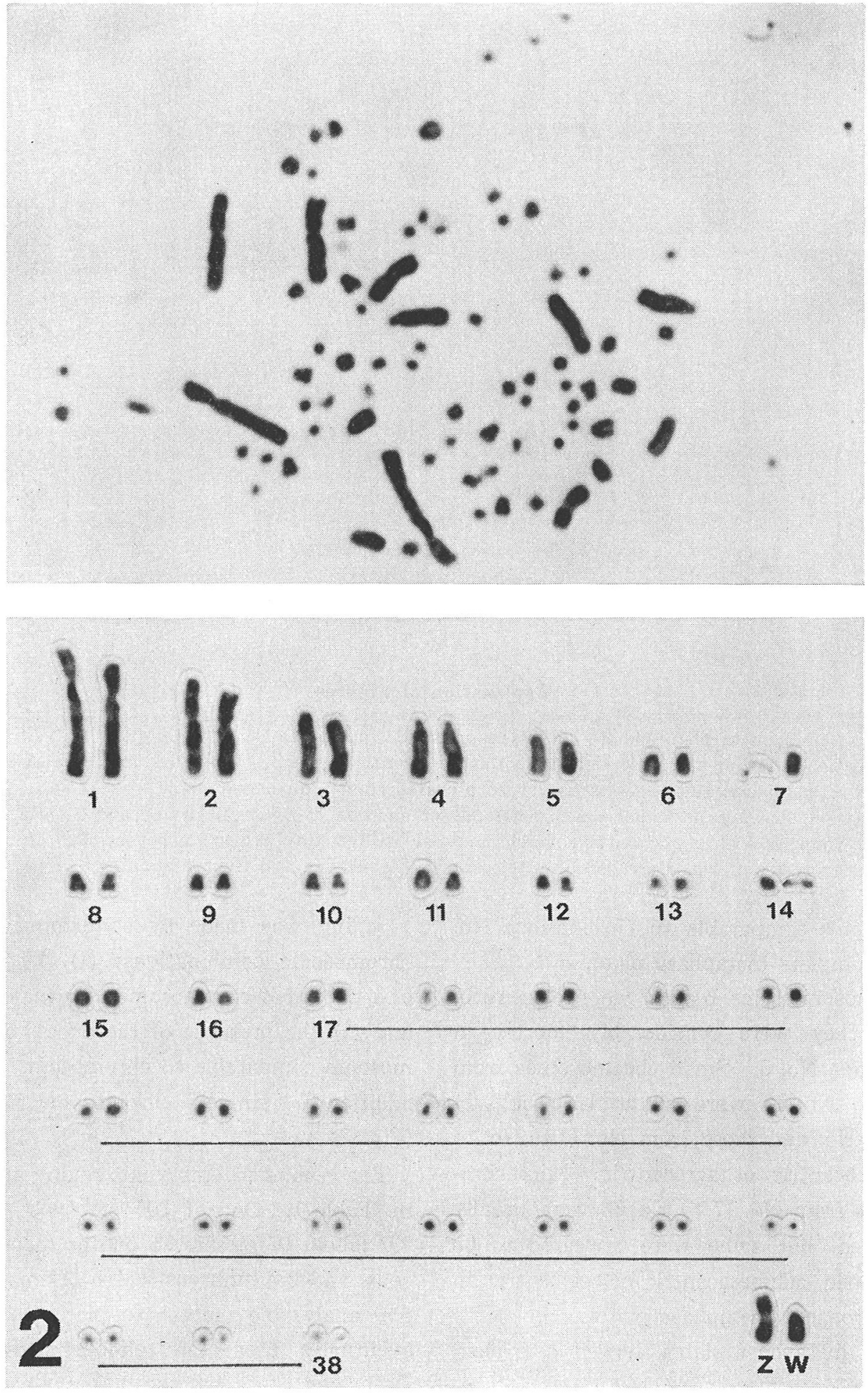

Fig. 2 


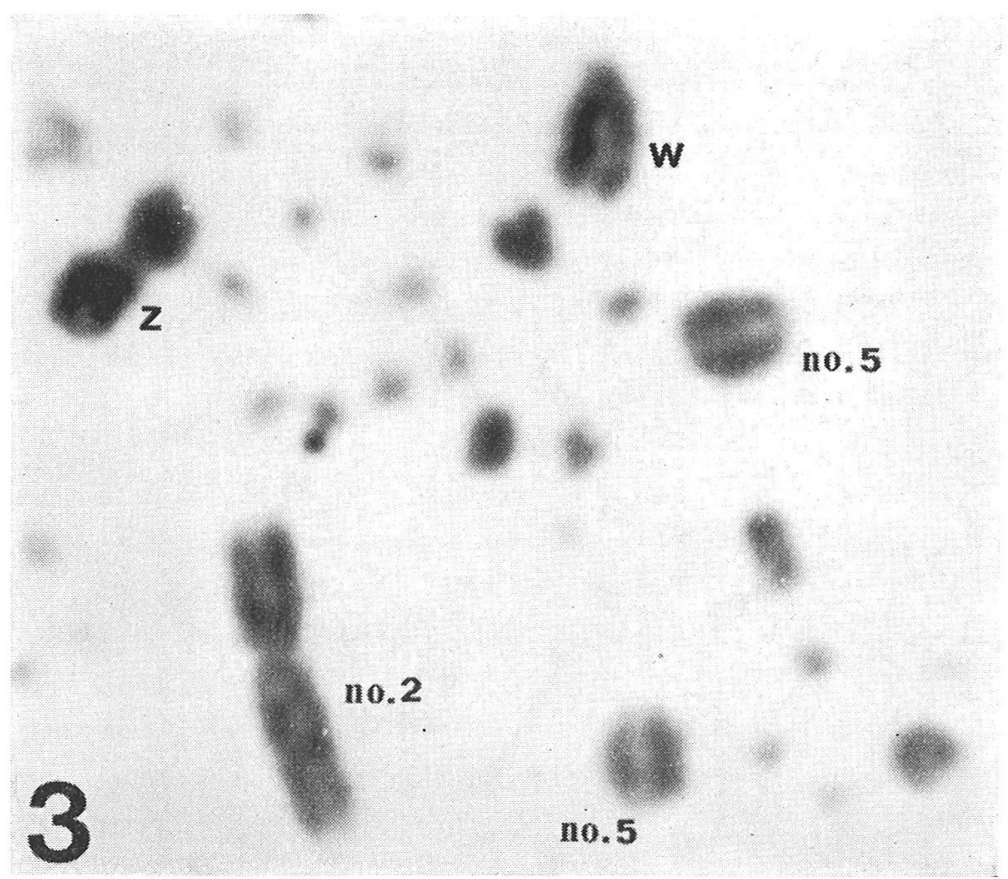

Fig. 3

\section{Explanation of Figures}

Fig. 1. A metaphase plate and its karyotype prepared from a quail embryonic disk at about 16 hours of incubation, showing the male sex-chromosome combination of ZZ. Air-drying and Giemsa staining Fig. 2. A metaphase plate and its karyotype prepared from a quail embryonic disk at about 16 hours of incubation, showing the female sex-chromosome combination of ZW. Air-drying and Giemsa staining Fig. 3. Showing with a presumptive $W$ chromosome with a tiny projection beyond the centromere. Two chromosomes of No. 5 are certainly telocentric. Air-drying and Giemsa staining

chromosome comparable to chromosome No. 5 in a complete metaphase plate.

Chromosomes Nos. 6 and 7 were telocentric, though they were considerably shorter in length then No. 5. Small chromosomes from No. 8 to No. 13 were metacentric or submetacentric, and those from No. 14 to No. 16 were telocentric or acrocentric. Microchromosomes from No. 17 to No. 38 were usually dot-shaped, but some were appeared to be metacentric, submetacentric or telocentric in better prepared metaphase plates.

A few metaphase plates showed a triploid number of chromosomes (117), without showing any other chromosomal aberration.
Sexing was made by confirming the sex chromosome combinations; (1) the presence of a pair of $Z$ chromosomes for male (Fig. 1) and (2) the presence of the excess one chromosome comparable to chromosome No. 5 in addition to a single $Z$ chromosome for female (Fig. 2).

The results of embryonic sexing are shown in Table 1. Out of 305 embryos prepared, 297 (about 97\%) showed one or more mitotic cells, and 274 embryos which offered at least five analyzable metaphase plates each were eventually used for reliable sexing with duplicated check by two different examiners. The ratio of successful sexing to the total of 
Table 1. Results of sexing quail embryos at about 16 hours of incubation

\begin{tabular}{cc}
\hline \hline No. of: embryos prepared & 305 \\
embryos showing one & \\
or more mitoses & $297(97.4 \%)$ \\
embryos sexed & $274(89.8 \%)$ \\
males & $138\}(50.4 \%$ males $)$ \\
females & $136)$ \\
\hline
\end{tabular}

embryos prepared was approximately $90 \%$. The embryos sexed as male were 138 and those sexed as female were 136, a sex ratio of 50.4 ( $\%$ males) being very close to equality.

\section{Discussion}

The normal diploid set of chromosomes in the quail is now definitely established ${ }^{6,8}$, although some discrepancy existed in the past $^{3,7)}$. It is composed of 38 autosome pairs and the sex chromosomes of $Z Z$ (male) or ZW (female).

In this study the sex-chromosome combinations were determined by a rather classical means solely depending on the comparison of chromosomal lengths and forms, but it may be justified by the following consideration.

The $\mathrm{Z}$ chromosome of the quail is known to be the third or the fourth largest and distinctive in its typical metacentric form ${ }^{3,6,7)}$. Also in our materials, it was easily identified, though sometimes found to be shorter than the fourth largest autosome.

On the contrary, the $\mathrm{W}$ chromosome of the quail has been explained variously as to its morphology. TALLURI and VEGNI ${ }^{8)}$ regarded it as a telocentric chromosome that is "a very little bit" shorter than chromosome No. 5 . BAMMI et al. ${ }^{3)}$ also recognized close similarities in both shape and length between the W chromosome and the sixth chromosome, but they regarded the sixth as sub-acrocentric.
(Their sixth chromosome corresponds to the chromosome No. 5 in this paper.) HARTUNG and $\mathrm{STAHL}^{8)}$ are of the opinion that the $\mathrm{W}$ chromosome is sub-telocentric and slightly bigger than chromosome No. 5. Some different descriptions were also made by other authors ${ }^{\text {B) }}$.

These diverse explanations seem to represent several aspects of the $\mathrm{W}$ chromosome which were shown by different procedures of preparation. It is certain that the $\mathrm{W}$ chromosome is generally comparable in length to the autosome pair of No. 5, although their lengths may vary to some extent due to their different condensation. It is also probable that the $\mathrm{W}$ chromosome is really acrocentric, but its apical projection is discernible only in better prepared metaphase plates. The latter consideration is also supported by our observations that the natural shapes of dot-shaped microchromosomes, such as metacentric, submetacentric and telocentric, were revealed only in better prepared metaphase plates. In any case, the presence of the $\mathrm{W}$ chromosome can be known by the finding of the three chromosomes comparable to chromosome No. 5 in an unbroken metaphase plate.

In this study, the sex ratio of 16-hour-old embryos measured $50.4 \%$ with no significant deviation from the fifty-fifty ratio. It is known that in the chicken two mortality peaks occur during the period of incubation, the first on day 2 or 3 and the second on day $18^{9)}$. Similar mortality peaks were observed in other species of poultry ${ }^{9)}$. In this study, the ratio of embryos missing mitotic figure was only $2.6 \%$ at 16 hours of incubation, showing less occurrence of embryonic mortality up to this earlier stage of incubation. Thus the value of sex ratio obtained in this study is considered to closely approximate 
to the primary sex ratio in our flocks of Japanese quail. Embryonic sex ratios during early developmental stages have also been studied in the fowl. FeCHHEIMER et al. ${ }^{1)}$ obtained a sex ratio of $49.5 \%$ in their cytological sexing at 16 to 18 hours of incubation. Muramatsu et al.$^{2)}$ sexed at five hours of incubation with a sex ratio of $50.1 \%$ in White Leghorn and 49.7\% in Barred Plymouth Pock. None of these authors recognized significant deviation from $50 \%$. Thus the numerical balance of the sexes seems to be maintained during the early stage of development in these birds.

On the other hand, the secondary sex ratio in the quail has been shown to favor the male. It was computed by Homma et al. ${ }^{10}$ at $52.5 \%$ with a significant deviation at the 2.5\% level. A high tendency of sex ratio after hatching is also observed by INo and SATo of Okayama University in their random breeding groups of Japanese quail (personal communication). The difference between the early embryonic sex ratio and the secondary one is suggestive of the occurrence of sex selective mortality during incubation. In the quail, embryonic mortality is likely to fall more heavily on females than on males.

\section{Acknowledgements}

We are indebted to Professor Tatsuo KUBo in this university for provision of a part of quail eggs for use.

\section{References}

1) Fechinimer NS, JR Lodge \& RC Miller: $J$. Reprod. Fert., 23, 365, 1970.

2) Muramatsu T, M Watanabe \& Y Nagashima: Bull. Agric. Utsunomiya Univ., 10 (3), 49, 1979.

3) BAMmI RK, RN SHOFFneR \& GJ HAIDEN: Can. J. Genet. Cytol., 8, 533, 1966.

4) Takashima Y \& Y Mizuma: Japan. Poultry Sci., $19(1)$, 53, 1982.

5) LEVAN A, K FREDGA \& AA SANDBERG: Hereditas, 52, 201, 1964.

6) TAlluRI MV \& L VegNi: Chromosoma (Berl.), 17, 264, 1965.

7) Shoffner RN, A Krishan, GJ Haiden, RK BAMmi \& JS OTIS: Poultry Sci., 46, 333, 1967.

8) Hartung M \& MA Stahl: C. R. Acad. Sc. Paris, 278, 2157, 1974.

9) KosIn IL: in Reproduction in Farm Animal, (HAFFz, ESE ed.) 2nd ed., p. 314, Lea \& Febiger, Philadelphia, 1968.

10) Hомma K, TD Siopes, WO WILSON \& LZ MCFarland: Poultry Sci., 45, 469, 1966.

(Received September 2, 1985) 


\title{
日本ウズラに拈ける早期胚の性判別と性比
}

\author{
吉沢 緑・野口征美*・村松 隆・岡本 昭 \\ (宇都宮大学農学部家畜種繁殖学教室 *現所属：三菱油化薬品研究所安全性グループ）
}

鳥胚の細胞学的性判別および性比の研究は, ニワトリ およびニワトリとウズラの雑種について行なわれている が, ウズラについてはまだ行なわれていない。本研究で は卯卵開始約 16 時間の胚の染色体標本を作製し, 性染 色体により性を決定し, 性比を求めた。

卯孚卵約 16 時間後に, 胚盤付近にコルセミドを注射し, 4 時間後に胚盤を摘出。自然乾燥法，または火炎乾燥法 により染色体標本を作製。ギムザ染色後, 検鏡。1 個体 につき, 78 本の染色体を有する中期核板を 5 個以上観察 し, 更に 2, 3 個の中期核板を写真撮影し, 性判別に供 した。性染色体のうち，Z 染色体は 4 番目に大きな中部 着系型であり, W 染色体は No. 5 の常染色体とほぼ同 じ大ささの次端部着系型であった。染色体の展開および
収縮が適度な中期核板では，W 染色体は No. 5 の端部 着系型染色体と明確に区別し得たが, 通常の標本では両 者の区別がつかない場合もあった。本研究では, $Z$ 染色 体が 2 個あるものを雄, $Z$ 染色体 1 個と No. 5 の大き さの染色体が 3 個（そのうちの 1 個はW染色体）あるも のを雌と判定した。性判別は, 2 人の観察者が別個に行 ない, それぞれの判定結果が一致するものについて性を 決定した。標本を作製した脹子は 305 個，そのらち 297 個 $(97.4 \%)$ で最低 1 個の分裂像が見られた。これらの らち最低 5 個の分析可能な中期核板を示し, 性判別が可 能であったものは 274 個 $(89.8 \%)$ であった。判別結果 は雄 138 個, 雌 136 個, 性比は $50.4 \%$ であり, 有意な 偏りは見られなかった。 